\title{
IMPACT OF CLIMATIC FACTORS TO THE PERCENTAGE OF YOUNG IN THE POPULATION OF BROWN HARE (Lepus Europaeus P) IN THE BAČKA DISTRICT
}

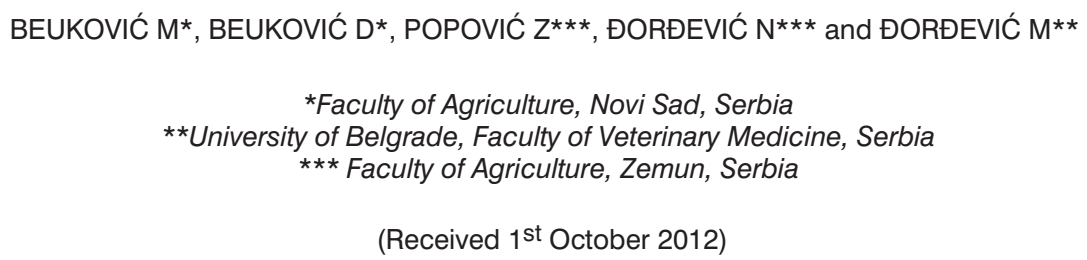

Climatic factors, especially temperature and precipitations, greatly affect the dynamics of the hare number and population. Climatic factors directly affect the physiological and reproductive processes of both individuals and entire populations, or indirectly, through the availability of food, competition with other species, predators and other. The age structure of the hare population at the end of the period of reproduction is an important indicator of the population growth that is used for planning the level of explotation of the hare population (hunting). The rational use of the hare's population is one of the most important protection procedures and it should be well monitored and controlled by the hunting professionals. We used the average monthly temperature and the sum of monthly precipitations in the hare reproductive period (March-September) during ten years (2000 - 2009), together with the percent of young in the hare population, on the territory of Bačka, for multiple regression (stepwise) analysis. Results of the regression analysis show an association between the percentage of young hares and the influence of climatic factors. The average temperature and sum of precipitation in June, are the strongest predictor of the percent of young in the hare's population in Bačka. According to the coefficient of determination $\left(R^{2}=0.50\right)$ climatic parameters account for $50 \%$ of variance in the percentage of young hares in Bačka. The regression correlation coefficient of all factors was $R=0.70$, which is on the border line between medium and high correlation.

Key words: Bačka, brown hare, climate factors, percent of young

\section{INTRODUCTION}

Hare (Lepus europaeus P.) is one of the most widespread and most frequent game species in Europe. The brown hare (Lepus europaeus P.) is an iconic species of European farmland regarded as an indicator of the quality of habitat for lowland agricultural landscapes (Cowan, 2004). The spatial distribution and 
Acta Veterinaria (Beograd), Vol. 63, No. 1, 111-122, 2013.

Beuković M et al.: Impact of climatic factors to the percentage of young in the population of brown hare (Lepus Europaeus P) in the Bačka district

abundance of the hare is primarily influenced by natural factors such as climate (Beuković et al., 2009a; Popović et al., 1996a, 1997), disease and predators (Beuković et al., 2011b; Popović et al., 2009) and to some extent by the anthropogenic factor, agricultural activities, transportation and hunting (Popović et al., 1996b). Particular importance is given to climatic factors, particularly temperature and precipitations in the period of reproduction in Serbia which is from March to September. Climatic factors directly affect the physiological and reproductive processes of individuals and entire populations, or indirectly through food availability, competition with other species, and other predators (Stenseth et al., 2002). According to DMI (2005) there are climatic predictions when are to be expected dynamic changes related to temperature increase between 0.6 and $4.6^{\circ} \mathrm{C}$ with a decrease in summer precipitation and increased risk of drought, which in unfavorable years may represent an additional risk to the hare population status. Increasing temperatures in the spring months can have a positive impact on hare populations at the global level (Reale et al., 2003). On the contrary, a large amount of precipitation in the spring months has a negative impact on the survival rate of young hares. In that respect, hare's are in advantage compared to rabbits that grow young under the ground, and therefore are more at risk from precipitation (Stott, 2008). During the summer, high temperatures, low precipitations and harvest of large agricultural areas under monocultures can lead to serious food shortages. Valencek et al. (2009) found out that as a result of food deficit in that period, changes also the energy value of hare's milk (from $14.5 \mathrm{JJg}^{-1}$ in spring to $11.03 \mathrm{kJg}^{-1}$ in the fall), which directly affects the growth of young hares.

In Serbia, the best habitat for hares are plains, which are mainly in Vojvodina, especially in Bačka. Hare populations in Vojvodina (Jovanović and Aleksić, 1976), have the first litter in early March, the second in April, the third in late May and early June, while the fourth and fifth are in July, late August and early September. Of these five litters, the first and the fifth are the least numerous, while the second and the third are the most numerous and have the most important influence on the percentage of young hares. Fertility of hares is great and it is the result of rapidly reached sexual maturity, as well as great participation of females in reproduction, and in particular, the large number of cubs per litter, and the long breeding period (Beuković et al., 2009b). The age structure of the hare population at the end of the period of reproduction is an important indicator of growth and as such is used in planning of usage level of hares on hunting grounds. Although hares can live for 10-15 years, in the present conditions only $3 \%$ hares reach the age of 4 years. Young hares (up to one year of age) consist of $50-75 \%$ of the autumn hare's population and the rest are mostly 1-2 years old. Rational use of populations and micro-populations of hares is one of the major forms of care for hares and should be entirely under the control of users of the hunting ground (Beuković et al., 2011). The aim of this study was to examine the relationship of temperature and amount of precipitation during the reproductive period of hares on the percentage share of young in the hare's population in Bačka. 


\section{MATERIAL AND METHODS}

In order to determine the influence of climatic factors (temperature and precipitations) on the percentage of young in the population of hares on the Bačka territory, the data was analyzed for the period from 2000. to 2009. The survey was conducted on a sample of 40,540 hunted hares during the mentioned period. Bačka district is a zone of moderate continental climate, with an average annual temperature of $10.9^{\circ} \mathrm{C}$ and an average annual precipitation of about $600 \mathrm{~mm}$, while the average annual relative humidity is $76.6 \%$. Bačka is from the west and south bordered by the river Danube and river Tisa, from the east, which is the natural border for the migratory movements of hares. Therefore, the population of hares in Bačka can be observed as a true entity. In Bačka (on a total 852,149 ha) was established 26 hunting grounds managed by hunting organizations. Categorization of the area with the percentage representation is shown in Table 1. The average size of hunting grounds is in a wide range from 5,000 ha to 100,000 ha. The structure of areas in Bačka is shown in Table 1, where the dominant share of arable land whose structure has a significant impact on the availability of food sources for the hare is noted.

Table 1. Type and structure of land in Bačka (Beuković et al., 2000)

\begin{tabular}{|l|r|c|}
\hline Type of land & ha & $\%$ \\
\hline \hline Forest & 19,536 & 2.30 \\
\hline Meadows and pastures & 39,684 & 4.66 \\
\hline Arable land & 699,542 & 82.09 \\
\hline Orchards and vineyards & 14,326 & 1.68 \\
\hline Ponds and reed & 8,515 & 1.00 \\
\hline Other land & 70,546 & 8.28 \\
\hline
\end{tabular}

Considering that formation of the first litter begins in early March and the last in September, the official statistical data were taken (Republic Hydrometeorological Service of Serbia), and that the average monthly temperature and monthly sum of precipitation for the period March to September. The percentage of young in the hare's population is determined for each area based upon analysis of the hare's age. Determination of the hare's age was based according to the mass of the intraocular lens.

The applied method is precise enough to determine the age of young hares (up to 9-10 months) so that with high reliability can differentiate young hares up to one year of age and adult hares, i.e. older than one year. The border mass of lens between young and adult hares in this study was $277.5 \mathrm{mg}(280 \mathrm{mg})$, which is consistent Šelmić reports (1984), Slamčeka et al. (1997), Pintur et al. (2006).

Hares eyes enucleated after hunting in the first hunts and delivered to the laboratory of the Hunting Association of Vojvodina, where they were tested. After extracting the lenses, fixation was done for 3 days in $10 \%$ formalin solution. Then the lenses were dried at $37^{\circ} \mathrm{C}$ for 72 hours. After drying, the measurements were 
carried out on an analytical scale, precision of $1 \mathrm{mg}$ (Šelmić et al., 1999). The method of determining the age structure of the population of hares by measurements of the mass of the intraocular lens is based on the fact that the lens of the eye grows throughout life, much more intensively during the first and second year of life, after which its growth slows (Lord, 1959; Rieck, 1962; Šelmić, 1984; Suchentrunck et al., 1991). Evaluation of the percentage of young in the population of hares is shown in Table 2.

Table 2. Classification participation of youth in the population of hares

\begin{tabular}{|c|c|c|c|c|c|}
\hline$\%$ young & Up to $40 \%$ & $41-50 \%$ & $51-57 \%$ & $58-63 \%$ & Over $64 \%$ \\
\hline \hline Characteristic & Very weak & Weak & Good & Very good & Excellent \\
\hline
\end{tabular}

Hunting Associations in Bačka are, depending on the geographical location, grouped under four meteorological stations: Rimski Šančevi, Bečej, Palić and Sombor, as Table 3 and Picture 1 show. The reason for this division is that the goal is to connect, as accurately as possible, the climatic parameters with the values of the percentage of young hares.

Table 3. Meteorological stations with belonging hunting grounds

\begin{tabular}{|c|c|c|c|}
\hline Bečej (1) & Rimski Šančevi (2) & Palić (3) & Sombor (4) \\
\hline \hline Bečej & Novi Sad & Subotica & Sombor \\
\hline Ada & Futog & Senta & Apatin \\
\hline Mol & Bačka Palanka & Bačka Topola & Kula \\
\hline Bačko Petrovo Selo & Bački Petrovac & Kanjiža & Vrbas \\
\hline Bačko Gradište & Titel & Mali Iđoš & Odžaci \\
\hline Nadalj & Žabalj & & Bač \\
\hline Turija & Temerin & & \\
\hline Srbobran & & & \\
\hline
\end{tabular}

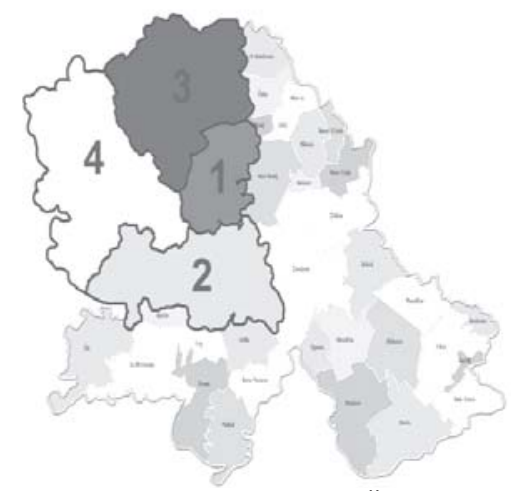

Picture 1. Meteorological stations: Bečej (1), Rimski Šančevi (2), Palić (3), Sombor (4) 
Acta Veterinaria (Beograd), Vol. 63, No. 1, 111-122, 2013.

Beuković $\mathrm{M}$ et al.: Impact of climatic factors to the percentage of young in the population of brown hare (Lepus Europaeus P) in the Bačka district

Statistical result analysis was performed with the software package "Statistica 10" (StatSoft, Inc.. 2011). For the analysis of the percent of young in the hare population and the average temperature and sum of precipitation during the reproduction period of the hare, GLM (general linear model ) with Fisher LSD test (least significant difference) was used. By multiple regression analysis simple correlation coefficients $(R)$ between the dependent variable (the percentage of youth in the population) and each potential indipendent variable (average monthly temperature and precipitation amount per month) were calculated.

\section{RESULTS AND DISCUSSION}

Table 4 shows that the average percentage of the values of the young in the population during a period of 10 years, varies between weather stations. Within the exposed data, a significant difference in the percent of young depending on the given year can be seen.

Table 4. Average percent of young in the hare population in Bačka, (\%)

\begin{tabular}{|c|c|c|c|c|c|c|c|c|c|}
\hline \multirow{2}{*}{\begin{tabular}{|c} 
Meteo. \\
stations \\
Years
\end{tabular}} & \multicolumn{2}{|c|}{ Bečej } & \multicolumn{2}{|c|}{ Palić } & \multicolumn{2}{|c|}{ Sombor } & \multicolumn{2}{|c|}{ R. Šančevi } & \multirow{2}{*}{$\begin{array}{c}\text { Avg. by } \\
\text { years }\end{array}$} \\
\hline & $\begin{array}{c}\text { Mean } \\
(\%)\end{array}$ & $\begin{array}{l}\text { Std. } \\
\text { Dev. }\end{array}$ & $\begin{array}{c}\text { Mean } \\
(\%)\end{array}$ & $\begin{array}{l}\text { Std. } \\
\text { Dev. }\end{array}$ & $\begin{array}{c}\text { Mean } \\
(\%)\end{array}$ & $\begin{array}{l}\text { Std. } \\
\text { Dev. }\end{array}$ & $\begin{array}{l}\text { Mean } \\
(\%)\end{array}$ & $\begin{array}{l}\text { Std. } \\
\text { Dev. }\end{array}$ & \\
\hline 2000. & 50.88 & 11.15 & 47.60 & 5.59 & 55.50 & 4.46 & 59.00 & 6.38 & $53.24^{b}$ \\
\hline 2001. & 60.25 & 8.63 & 56.80 & 8.35 & 62.17 & 4.71 & 62.29 & 4.15 & $60.38^{f}$ \\
\hline 2002. & 60.50 & 12.77 & 57.20 & 8.73 & 62.00 & 4.34 & 65.43 & 9.14 & $61.28^{f}$ \\
\hline 2003. & 50.00 & 3.24 & 44.60 & 11.44 & 56.00 & 7.72 & 54.43 & 6.80 & $51.26^{a}$ \\
\hline 2004. & 70.75 & 9.87 & 56.00 & 6 & 63.33 & 6.28 & 59.57 & 4.28 & $62.41^{\mathrm{F}}$ \\
\hline 2005. & 64.00 & 6.07 & 66.80 & 4.76 & 65.83 & 5.78 & 65.00 & 3.16 & $65.41^{\mathrm{g}}$ \\
\hline 2006. & 49.75 & 14.21 & 55.80 & 10.66 & 58.67 & 5.05 & 57.29 & 7.80 & $55.38^{\mathrm{C}}$ \\
\hline 2007. & 57.50 & 10.25 & 57.60 & 8.7 & 64.00 & 7.56 & 57.71 & 9.34 & $59.20^{e}$ \\
\hline 2008. & 56.50 & 8.68 & 41.20 & 8.07 & 57.67 & 7.94 & 64.29 & 16.28 & $54.91^{b}$ \\
\hline 2009. & 60.75 & 15.86 & 50.40 & 5.13 & 54.17 & 3.13 & 61.71 & 7.48 & $56.76^{c}$ \\
\hline $\begin{array}{l}\text { Avg. by } \\
\text { stations }\end{array}$ & $58.09^{A}$ & 6.69 & $53.40^{\mathrm{B}}$ & 7.49 & $59.93^{A}$ & 4.05 & $60.67^{A}$ & 3.67 & \\
\hline
\end{tabular}

Std. Dev. - Standard deviation value for \% of young in hare populations between Hunting grounds within corresponding station by years;

Avg. by stations - Average value for \% of young in hare populations during 10 years by stations; Avg. by years - Average value for $\%$ of young in hare populations during 10 years by years;

A-B Values with the superscript in row Avg. by stations are significantly different $(p<0.01)$ A-A Values with the superscript in row Avg. by stations are not significantly different $(p>0.05)$; a-b; a-c; b-c; b-b, , b-e, c-e, e-f, e-g, g-f, F-f, F-e, F-g Values with the superscript in column Avg. by years are not significantly different $(p>0.05)$;

$a-e, b-f$ Values with the superscript in column Avg. by years are significantly different $(p<0.05)$; a-f, a-g, b-F, b-g, a-F, c-g Values with the superscript in column Avg. by years are significantly different $(p<0.01)$ 
Average values of young hares in the population of Bačka for the period 2000-2009. grouped in concurrency to meteorological stations, vary in a rather wide range. The reasons for such large variations are the result of the caracteristics of hunting grounds and respective management of hares. The smallest percentage share $(53.40 \%)$ of young in a hare's population was recorded at the weather station Palić, which according to Table 2 can be evaluated as "good". Within the meteorological station Bečej the percentage of young in the population of hares was $58.09 \%$ which according to Table 1 can be evaluated as "very good". The "very good" evaluation is valid also for the weather stations Sombor and Rimski Šančevi, where the percents of young in the population were $59.93 \%$ and $60.67 \%$, respectively. If we look at row "Average by stations", we can see that between the average values of young in the population during the decade (Table 4$)$ there were significant differences $(p<0.01)$ between the Palić station and others. Between the values recorded at Rimski Šančevi, Sombor and Bečej there were no significant differences $(p>0.05)$.

When we look at the column "Average by years", whose mutual relation of significance is shown in Table 4, we can see cycles in the percent of young in the hare population, over the 10 years. So year 2000 and 2003 are marked as the years with the lowest percent of young in the hare population versus year 2005 and 2004.

Table 5 shows the average temperature during the reproductive period of a hare, at the stations over a period of 10 years (2000-2009).

Table 5. Average temperature during the period March-September $\left({ }^{\circ} \mathrm{C}\right)$

\begin{tabular}{|c|c|c|c|c|c|c|c|c|c|c|}
\hline Station & 2000. & 2001. & 2002. & 2003. & 2004. & 2005. & 2006. & 2007. & 2008. & 2009. \\
\hline \hline Bečej & 18.1 & 16.9 & 17.8 & 18.3 & 16.4 & 16.3 & 17.1 & 18.5 & 17.9 & 18.6 \\
\hline Palić & 17.8 & 16.7 & 17.8 & 17.9 & 16.2 & 15.9 & 16.6 & 17.8 & 17.1 & 17.9 \\
\hline R. Šančevi & 18.0 & 16.6 & 17.5 & 17.9 & 16.0 & 15.8 & 16.6 & 17.6 & 17.3 & 17.8 \\
\hline Sombor & 17.9 & 16.5 & 17.2 & 18.0 & 15.7 & 15.8 & 16.5 & 17.6 & 17.0 & 17.7 \\
\hline $\begin{array}{c}\text { Avg. } \\
\text { Std. Dev. }\end{array}$ & $\begin{array}{c}17.9^{\mathrm{C}} \\
( \pm 0.12)\end{array}$ & $\begin{array}{c}16.7^{\mathrm{A}} \\
( \pm 0.17)\end{array}$ & $\begin{array}{c}17.6^{\mathrm{C}} \\
( \pm 0.28)\end{array}$ & $\begin{array}{c}18.0^{\mathrm{C}} \\
( \pm 0.19)\end{array}$ & $\begin{array}{c}16.1^{\mathrm{B}} \\
( \pm 0.30)\end{array}$ & $\begin{array}{c}16.0^{\mathrm{B}} \\
( \pm 0.24)\end{array}$ & $\begin{array}{c}16.7^{\mathrm{A}} \\
( \pm 0.27)\end{array}$ & $\begin{array}{c}17.9^{\mathrm{C}} \\
( \pm 0.43)\end{array}$ & $\begin{array}{c}17.3^{\mathrm{E}} \\
( \pm 0.40)\end{array}$ & $18.0^{\mathrm{C}}$ \\
$( \pm 0.41)$
\end{tabular}

$A-A, B-B$; C-C, $C-E, C-C-$ Values with the superscript are not significantly different $(p>0.05)$;

$A-B, A-C, C-B, A-c, A-E, C-E, B-C-$ Values with the superscript are significantly different $(p<0.05)$; Std. Dev. - Standard deviation between stations within corresponding years;

Avg. - Average value for March - September temperature mean by years:

We can see a significant difference between the extreme years 2000 and $2007\left(17.9^{\circ} \mathrm{C}\right), 2003$ and $2009\left(18.0^{\circ} \mathrm{C}\right)$ which were extremely hot as opposed to $2004\left(16.1^{\circ} \mathrm{C}\right)$ and $2005\left(16.0^{\circ} \mathrm{C}\right)$. Also there is a noticeable cycle of hot years, which generally coincides with a cycle of low percentage of young in the population of hares (Table 4). If we consider the fluctuations in temperature between stations over the years, we can see that 2009, 2008 and 2007 have the highest standard deviation. Lowest fluctuations in temperature between stations were recorded during the years 2000 and 2001. 
Low spring and extremely high temperatures during the summer months, negatively affect the reproduction of hares while higher temperatures in the fall extend the season of reproduction (Frylestam, 1979; 1980). Hares are particularly sensitive to unfavorable weather conditions, as well as bacterial and parasitic infections that can be caused and easily transmitted during certain meteorological conditions (Goszczynski and Wasilevski 1992; Hacklander et al., 2002).

Table 6 shows the average quantity of precipitation $(\mathrm{mm})$ during the hare reproductive period (March-September), where can be seen large variations of this parameter in the observed years. It is evident that 2000 and 2003. were the years with the lowest level of precipitation for the period March-September (Table 6). These two extreme years with poor precipitation had a negative impact on the percent of young in the hare population (Table 4).

Table 6. Amount of precipitation for period March-September ( $\mathrm{mm})$

\begin{tabular}{|c|c|c|c|c|c|c|c|c|c|c|}
\hline Station & 2000. & 2001. & 2002. & 2003. & 2004. & 2005. & 2006. & 2007. & 2008. & 2009. \\
\hline Bečej & 174.3 & 634.9 & 367.5 & 216.6 & 415.7 & 523.8 & 439.7 & 404.7 & 318.0 & 257.8 \\
\hline Palić & 177.8 & 660.2 & 277.2 & 218.7 & 456.8 & 560.2 & 505.3 & 361.8 & 490.1 & 332.9 \\
\hline R. Šančevi & 179.8 & 817.9 & 289.0 & 225.9 & 476.2 & 570.4 & 492.5 & 446.4 & 376.0 & 306.1 \\
\hline Sombor & 180.7 & 606.5 & 366.7 & 187.2 & 521.7 & 634.7 & 475.6 & 372.7 & 456.9 & 278.0 \\
\hline Avg. & $\begin{array}{l}178.2^{\mathrm{A}} \\
\pm 2.84\end{array}$ & $\begin{array}{c}679.9^{\mathrm{B}} \\
\pm 94.6\end{array}$ & $\begin{array}{l}325.1^{\mathrm{e}} \\
\pm 48.74\end{array}$ & $\begin{array}{l}212.1^{\mathrm{A}} \\
\pm 17.07\end{array}$ & $\begin{array}{l}467.6^{\mathrm{D}} \\
\pm 44.01\end{array}$ & \begin{tabular}{|}
$572.3^{\mathrm{C}}$ \\
\pm 46.17
\end{tabular} & $\begin{array}{l}478.3^{\mathrm{D}} \\
\pm 28.45\end{array}$ & \begin{tabular}{|l|}
$396.4^{d}$ \\
\pm 37.98 \\
\end{tabular} & \begin{tabular}{|l|}
$410.3^{\mathrm{D}}$ \\
\pm 77.96
\end{tabular} & $\begin{array}{l}293.7^{\mathrm{E}} \\
\pm 32.79\end{array}$ \\
\hline
\end{tabular}

$A-A, D-D, e-E, d-e, D-d-$ Values with the superscript are not significantly different $(p>0.01)$;

$A-B, A-C, C-B, A-E, A-e, A-d C-E-V a l u e s$ with the superscript are significantly different $(p<0.01)$; Std. Dev. - Standard deviation between stations within corresponding years;

Avg. - Average value for March - September precipitation sum by years

The wettest year was 2001 (679.9 mm, March-September), which along with 2005 and 2006 (572.3 $\mathrm{mm}$ and $478.3 \mathrm{~mm}$, respectively) are significantly different compared to year $2000(178.2 \mathrm{~mm})$ and 2003. (212.1 mm). This cycle of drought and rainy years may be associated with the above cyclic values of temperature and percentage of young in the population. So we can see that the extreme drought in 2000 and 2003 year coincide with the lowest percentage of young. This way remains masked the impact of heavy rains in the months that are essential for the development of litters. Therefore, the inclusion of the original values of climatic parameters on a monthly basis in correlation models in comparison with the percentage of young hares, is important for determing the correlation strength, as well as the determination of the most important periods.

Table 7 shows the results of multiple regression analysis relating to the percentage of zoung in the hare population and effect of climatic factors in Bačka.

Predictors in Table 7 are ordered according to strength, or the amount of the standard regression coefficient $(\beta)$. The first three predictors are significant at $p<0.05$, while the others were not significant $p>0.05$, but in combination with other predictors, have an effect on the model. Other predictors are not shown in 
Table 7, as stepwise analysis was not selected because they have no impact on the model.

Table 7. Multiple Regression (Stepwise) Analysis: Climate parameters as a predictor of the percentage of youth in the hare's population of Bačka

\begin{tabular}{|c|c|c|}
\hline & Beta $(\beta)$ & Summary of model \\
\hline June Temperature & $-0,86^{\star}$ & \multirow{6}{*}{$\begin{array}{c}\text { Multiple } R=0.70 \\
R^{2}=0.5 \\
\text { Intercept }=136.6\end{array}$} \\
\hline June Precipitation & $-0,79^{*}$ & \\
\hline September Precipitation & $0,52^{*}$ & \\
\hline April Precipitation & -0.23 & \\
\hline August Temperature & -0.20 & \\
\hline May Precipitation & 0.18 & \\
\hline
\end{tabular}

Beta ( $\beta$ - -standard regression coefficient,

Betas with * in superscript are significantly different $(p<0.05)$

$R$ - Regression correlation coefficient of all factors,

$\mathrm{R}^{2}$ - coefficient of determination,

Intercept - average value of $\mathrm{Y}$ when $\mathrm{X}=0$

According to the coefficient of determination $\left(R^{2}=0.5\right)$ shown in Table 7 , the observed climatic parameters explain $50 \%$ of variance in the percentage of young hares in Bačka $\left(R^{2} \star 100\right)$. The regression coefficient of correlation of all factors together shown in Table 7, was $R=0.7$, which is on the border of medium and high correlation.

The size and direction of the regression coefficient indicates that lower temperatures and to a smaller extent the sum of rainfall in June and higher precipitation in September, have a positive effect on the percent of young in the hare population in Bačka

$$
\hat{Y}=136.6+0.52 x_{1}-0.79 x_{2}-0.86 x_{3}
$$

$\hat{Y}$ - dependent variable, Percent of young in hare population

$\mathrm{x}_{1}$ - independent variable, September Precipitation

$x_{2}$ - independent variable, June Precipitation

$x_{3}$ - independent variable, June Temperature

Formula 1 The equation of multiple regression analysis: climatic parameters as a predictor of percent of young in the hare population in Bačka.

Using Formula 1 obtained by regression analysis, it is possible to predict the values of the percentage of young in the hare's population on the territory of Bačka, in the following year based on the values of temperature and sum of precipitation in June and sum of precipitation September of the given station.

During multiple regression analysis of the impact of temperature and precipitation on the percent of young in the population, a statistically significant correlation for June was determined, as in this month is the majority of third litters whose share has the greatest impact on the percentage of young in the 
population of hares. The importance of the third (June litter) in previous studies was pointed out (Jovanović et al., 1971; Jovanović and Aleksić, 1976), while in the research of Popović et al. (1997) the authors state a higher impact of the fourth and third litters.

During the research of the impact of meteorological factors on the number of hares in Vojvodina from 1968. to 1970. for the period February - May, Jovanović et al. (1971) found that there is a relationship between the average monthly temperature in May and the percentage of young hares while this is not the case for the other months. In the same study, no relationship was found between the sum of precipitation and hare growth. Popović et al. (1997) studied and proved the impact of average monthly temperatures and average monthly precipitations on the percentage of young in the population of hares in Vojvodina during the period March-August from 1974. to 1992.

These authors concludde that the rainfalls in July are statistically a very significant factor $(p<0.01)$, while in May and June they are on the margin of statistical significance $(p<0.05)$. The rest of monthly periods of reproduction are not statistically significant. Popović et al. (1997) report that average monthly temperature is not statistically significant $(p>0.05)$. The different results are the result of insufficient of comprehensive analysis, as the mentioned authors connect the average monthly temperature and precipitation to the average percentage of young in the hare population based on the value for all of Vojvodina during the years. Instead, in our paper, the climatic parameters are associated with the percent of young in the hare population on the hunting grounds, and they are grouped in meteorological stations (four), for which the parameters were analyzed and compared through the years.

In his paper, Smith et al. (2005) carried out an analysis of 77 papers from 12 countries where the conclusions were derived that climatic factors are, besides others, significantly associated with the hares population, whereas precipitation together with predators and intensifying of agricultural production have a highly significant negative impact on the populations of hares. These authors in their review, report that since 1961 there has been a general increase in temperature, particularly during winter, of up to $2^{\circ} \mathrm{C}$ throughout Europe (Schönwiese and Rapp, 1997), a change that should benefit hares rather than cause a decline. Precipitation has increased in western and parts of eastern Europe, and decreased in parts of central Europe (Schönwiese and Rapp, 1997). The combined increase in winter temperature and precipitation may have increased the rates of disease transmission over the last few decades (Barre et al., 1978; Eiberle et al., 1982; Edwards et al., 2000).

The conclusion is that the percentage of young in the population depends not only on the climate, but also on many other factors, and one particularly significant is anthropogenic (Beuković et al., 2011). Considering that in Europe and Serbia, the largest number of hares live on arable land it means that their abundance is directly dependent on agricultural activities (Reichlin et al., 2006; Katona et al., 2004; 2010). Some authors explain for the lower survival rate of leverets $(0.17)$ could be related to climate, food availability and impaired energy budgets (Hackländer, et al. 2002). 


\title{
CONCLUSION
}

According to the presented and analyzed data of average monthly temperatures and monthly sums of precipitation between March-September observed during 10 years (2000-2009), we can present the following conclusions:

- The percentage of young hares during 10 years by stations was assessed as "very good" for Rimski Šančevi $(60.67 \% \pm 3.67)$, Bečej $(58.09 \% \pm 6.69)$, and Sombor (59.93\% 4.05$)$ and "good" for Palić (53.40\% \pm 7.49$)$.

- Lower June temperatures, a lower sum of rainfall in June and higher sum precipitation in September, have an impact on the higher percent of young in the population of hares in Bačka.

- The influence of climatic factors on the third-litter have great significance for the participation of young in the overall population of hares in Bačka.

\section{ACKNOWLEDGEMENTS:}

The work is a part of the research on the project TP-31009, financed by the Ministry of Education and Science, Republic of Serbia.

\author{
Address for correspondence: \\ Prof. dr Miloš Beuković \\ Faculty of Agriculture \\ Trg D. Obradovića 8 \\ 21000 Novi Sad, Serbia \\ E-mail: milos.beukovic@stocarstvo.edu.rs
}

\section{REFERENCES}

1. Barre N, Louzis C, Tuffery G, 1978, Contribution à l'étude epidemiologique de l'infection a Yersinia pseudo-tuberculosis chez les animaux sauvages en France. Bulletin Mensuel, 67-82, Nationale de la Chasse.

2. Beuković M, Šelmić V, Jović D, Vapa, M, Puzović M, Pantelić A et al., 2000, Dugoročni program razvoja lovstva Vojvodine 2000-2010. godine, Novi Sad.

3. Beuković M, Popović Z, Maletić V, Beuković D, Đoković D, 2009a, Vlijanie na klimatskite faktori vrz procentot na mladi vo populacijata na zajakot (Lepus Europaeus Pall) vo Vojvodina, IV International Symposium of Livestock Production, Struga, Macedonia, 09-12.09.2009, Proceedings, 232.

4. Beuković M, Beuković D, Popović Z, Perišić P, 2009b, Number and usage level dynamics of population brown hare (Lepus Europaeus) round of river Tisa in Bačka district, Zbornik naučnih radova Instituta PKB Agroekonomik, 15, 173-9.

5. Beuković M, Đorđević N, Popović Z, Beuković D, Đorđević M, 2011a, Nutrition specificity of brown hare (Lepus Europaeus) as a cause of the decreased number of population, Contemp Agricult, 60, 403-13.

6. Beuković M, Tepavac K, Beuković D, Đorđević N, Popović Z, Đorđević M, 2011b, Biometric characteristic jackal (Canis aureus L.) in Vojvodina, 22nd International symposium "Safe food production", Trebinje, Bosnia and Hercegovina, 19-25 June, 2011, Proceedings, 19-21.

7. Cowan $D$ (2004) An overview of the current status and protection of the Brown Hare (Lepus europaeus) in the UK. Defra report prepared for European Wildlife Division.

8. DMI, Danmarks Meteorologiske Institut, (2005), Final Report 1 November 2001 - 31 October 2004. WEB: http://prudence.dmi.dk/public/ publications/ PRUDENCE\%20Final\%20report.pdf

9. Eiberle K, Matter J, Wettmann O, 1982, Zur Bestandesentwicklung des Feldhasen im Kanton Zürich.Vierteljahrsschrift der Naturforschenden Gesellschaft in Zürich, 127, 231-45. 
10. Erlinge S, Frylestam B, Göransson G, Högstedt G, Liberg O, Loman J, (1984) Predation on brown hare and ring-necked pheasant populations in southern Sweden, Holarctic Ecol, 7, 300-4.

11. Frylestam B, 1979, Structure, size and dynamic of three European hare populations in southern sweden, Acta Theriol, 24, 449-64.

12. Frylestam B, 1980, Utilazition of farmland habitats by European hares (Lepus Europeaus) in Soutern Sweden, Viltravy, 11, 271-48.

13. Goszczynski J, Wasilewski M, 1992, Predation of foxes on a hare population in Central Poland, Acta Theriol, 37, 4, 329-38.

14. Hacklander K, Arnold W, Ruf T, 2002, Postnatal development and thermoregulation in the precocial European hare (Lepus europaeus), J Comp Physiol B, 172, 183-90.

15. Jovanović V, Kostić $P$, Aleksić $D$, 1971, Prilog u proučavanju realnog godišnjeg prirasta zečeva u Vojvodini i uticaj meteoroloških elemenata na taj priraštaj, Simpozijum o lovstvu, Beograd, 13647.

16. Jovanović V, Aleksić $D, 1976$, Prilog proučavanju meteoroloških elemenata na realan godišnji priraštaj zeca u Vojvodini, Simpozijum o lovstvu, Beograd, Zbornik radova, 291-7.

17. Lord $R D, 1959$, The lens as an indicator age in cottontal rabits, $J$ Wildl Manage, 23.

18. Katona K, Biro Zs, Hahn I, Kertesz I, Altbäcker V, 2004, Competition between European hare and European rabbit in a lowland area, Hungary: a long-term ecological study in the period of rabbit extinction, Folia Zool, 53, 255-68.

19. Katona K, Biro Zs, Szemethy L, Demes T, Nyeste M, 2010, Spatial, temporal and individual variability in the autumn diet of european hare (Lepus europaeus.) in Hungary, Acta Zool Acad Sci Hung, 56, 89-101.

20. Pintur K, Popović N, Alegro A, Severin K, Slavica A, Kolić E, 2006, Selected indicators of Brown hare (Lepus Europaeus Pallas, 1778) population dynamics in northwestern Croatia, Vet arhiv, 76, 199-209.

21. Popović Z, Gajić I, Bogdanović V, 1996a, Uticaj klimatskih činilaca na učešće mladih u populaciji zeca, 5. kongres ekologa Jugoslavije, Beograd, 22-27. septembar 1996, Zbornik sažetaka, 74.

22. Popović Z, Bogdanović V, Gajić I, 1996b, Analiza promene brojnosti zeca u našoj zemlji, Savetovanje u Prokuplju i Kikindi 1995. godine, Lovački savez Jugoslavije, Zbornik radova, 121-32.

23. Popović Z, Bogdanović V, Gajić I, 1997, The influence of climatic factors on the percipitation of young in the hare's population (Lepus Europaeus Pall.), V Kongres Ekologija Jugoslavije, Beograd, Proceedings, 32, 139-44).

24. Popović Z, Đorđević N, Beuković M, 2009, Nourishment of game from the carnivora order damages and benefits in hunting economy, forestry and agriculture, Contemp Agricult, 58, 3-4, 150-6.

25. Reale D, McAdam A, Boutin G, Berteaux S, 2003, Genetic and plastic responses of a northern mammal to climatic change, Proc $R$ Lond, B270, 591-6.

26. Reichlin T, Klansek E, Hackländer K, 2006, Diet selection by hares (Lepus europaeus) in arable land and its implications for habitat management, Europ J Wildlife Res, 52, 109-18.

27. RieckW, 1962, Analyse von Feldhasenstrecken nach dem Gewicht der Augenlinse, Supll. Ricerche di Zoologia appl. alla Caccia, Vol. IV, Bologna.

28. Republički hidrometeorološki zavod Srbije, 2011, Meteorološki godišnjak 2000-2009, klimatološki podaci. WEB: http://www.hidmet.gov.rs/ciril/meteorologija/klimatologija_godisnjaci.php

29. Slamečka J, P Hell, R Jurčík, 1997, Brown hare in the Westslovak Lowland, Acta Sc Nat Brno, 31, 21-28, 100-3.

30. Smith RK, Jennings NV, Harris S, 2005, A quantitative analysis of the abundance and demography of European hares Lepus europaeus in relation to habitat type, intensity of agriculture and climate, Mammal Rev, $35,1,1-24$.

31. StatSoft, Inc., 2011, Electronic Statistics Textbook. Tulsa, OK: StatSoft. WEB: http://www.statsoft.com/textbook/. 
32. Stenseth NC, Ottersen G, Hurrell JW, Mysterud A, Lima M, 2002, Ecological effects of climate fluctuations, Science, 297, 1292-6.

33. Stott $P, 2007$, Comparisons of digestive function between the European hare (Lepus europaeus) and the European rabbit (Oryctolagus cuniculus): Matication, gut passage, and digestibility, Mammal Biol, 73, 276-86.

34. Schönwiese, C. and Rapp, J., 1997, Climate Trend Atlas of Europe Based on Observations, 1891-1990. Kluwer Academic Publishers, Dordrecht.

35. Suchentrunck F, Willing F, Hartl GB, 1991, On eye lens weights and other age criteria of the Brown hare (Lepus europaeus Pallas, 1778, Z Säugetierkd, 56, 365-74.

36. Šelmić V, 1984, Proučavanja zakonomernosti dinamike populacije zeca u Vojvodini i njihova primena u planiranju racionalnog korištenja, Disertacija, Šumarski fakultet Beograd, Srbija.

37. Šelmić V, Đaković $D$, Novkov M, 1999, Istraživanja realnog prirasta zečijih populacija i mikropopulacija u Vojvodini, Godišnji izveštaj o naučnoistraživačkom radu u organizaciji.

38. Valencak TG, Tataruch F, Ruf T, 2009, Peak energy turnover in lactating European hares: The role of fat reserves, J Exp Biol, 212, 231-7.

\title{
UTICAJ KLIMATSKIH FAKTORA NA PROCENAT MLADIH U POPULACIJI ZECA (Lepus Europaeus P.) U BAČKOJ
}

\author{
BEUKOVIĆ M, BEUKOVIĆ D, POPOVIĆ Z, ĐORĐEVIĆ N i ĐORĐEVIĆ M
}

\section{SADRŽAJ}

Klimatski faktori, pre svega temperatura i količina padavina, utiču u velikoj meri na brojnost i dinamiku populacije zeca. Oni utiču direktno na fiziološke i reprodukcione procese kako jedinke tako i cele populacije, ili indirektno, preko dostupnosti hrane, konkurencije sa drugim vrstama, predatora i dr. Starosna struktura zečije populacije na kraju perioda razmnožavanja je važan pokazatelj prirasta koji se koristi pri planiranju stepena korišćenja zeca u lovištima. Racionalno korišćenje populacija i mikropupulacija zeca je jedan od najzanačajnijih oblika zaštite zeca i trebao bi da bude u potpunosti pod kontrolom korisnika lovišta. Multiplom regresionom analizom prosečnih mesečnih temperaturnih vrednosti $i$ sume mesečnih padavina za reprodukcioni period (mart-septembar) od 2000. do 2009. godine na teritoriji Bačke, izračunati su regresioni koeficijenti za prosečne temperaturne vrednosti, odnosno sume mesečnih padavina. Rezultate regresione analize povezanosti procenta mladih zečeva i uticaja klimatskih faktora na području Bačke ukazuju da su prosečne temperature i padavine u junu, najjači prediktor. Prema koeficijentu determinacije $\left(R^{2}=0,50\right)$ klimatski parametri objašnjavaju $50 \%$ varijanse procenta mladih zečeva na području Bačke. Regeresioni koeficijent korelacije svih faktora zajedno iznosio je $R=0,70$, što je na granici srednje i jake povezanosti. 